\title{
Retraction Note to: Land vegetation cover based on deep learning and optimization of online English teaching mode
}

\section{Fengqin Zhang ${ }^{1}$}

Published online: 4 November 2021

C) Saudi Society for Geosciences 2021

Retraction Note to: Arabian Journal of Geosciences (2021) 14: 1671 https://doi.org/10.1007/s12517-021-07861-2

The Editor-in-Chief and the Publisher have retracted this article because the content of this article is nonsensical. The peer review process was not carried out in accordance with the Publisher's peer review policy. The author has not responded to correspondence regarding this retraction. 